\title{
Kelimpahan Zooplankton Sebagai Indikator Kesuburan Perairan Di Rawa Banjiran Desa Sedang Kecamatan Suak Tapeh Kabupaten Banyuasin
}

\author{
Indah Anggraini Yusanti \\ e-mail: indahayusanti@gmail.com \\ Program Studi Ilmu Perikanan Fakultas Perikanan \\ Universitas PGRI Palembang
}

\begin{abstract}
The study of zooplankton abundance as an indicator of water fertility in the Banjiran swamp in the Sedang Village of Suak Tapeh Subdistrict, Banyuasin Regency was conducted in July to August 2017. The zooplankton sampling method was carried out at 3 (three) stations namely nebong kuning swamp station (station 1), poron swamp (station 2) and banan swamp (station 3) using purposive random sampling method. Data obtained in this study include data on zooplankton composition, zooplankton abundance index and zooplankton dominance index. While the data analysis was carried out descriptively. The results of zooplankton identification obtained during the study found 8 (eight) genera of zooplankton consisting of 3 (three) classes, namely Monogononta 1 genus, Mastigophora 5 genus and Ciliate 2 genus. The highest zooplankton abundance was found at station 1 kuning nebong swamp and banan swamp with an average value of 1.75 ind / $\mathrm{L}$ and $1,5 \mathrm{ind} / \mathrm{L}$ indicating the level of fertility of the floodwaters belongs to the mesotrophic category and the lowest at station 2 poron swamp with an average value of 0.92 ind / L indicating the level of fertility of the floodwaters in the Sedang village of Suak Tapeh Subdistrict, Banyuasin Regency belongs to the oligotrophic category.
\end{abstract}

Keywords: abundance, zooplankton, flood swamp, water fertility

\begin{abstract}
ABSTRAK
Penelitian tentang kelimpahan zooplankton sebagai indikator kesuburan perairan di rawa banjiran Desa Sedang Kecamatan Suak Tapeh Kabupaten Banyuasin telah dilakukan pada Juli sampai dengan Agustus 2017. Metode pengambilan sampling zooplankton dilakukan pada 3 (tiga) stasiun yaitu stasiun rawa nebong kuning (stasiun 1), rawa poron (stasiun 2) dan rawa banan (stasiun 3) dengan menggunakan metode purposive random sampling. Data yang di dapat pada penelitian ini meliputi data komposisi zooplankton, indeks kelimpahan zooplankton dan indeks dominansi zooplankton. Sedangkan analisis data dilakukan secara deskriptif. Hasil identifikasi zooplankton yang diperoleh selama penelitian ditemukan 8 (delapan) genus zooplankton yang terdiri dari 3 (tiga) kelas yaitu kelas Monogononta 1 genus, Mastigophora 5 genus dan Ciliata 2 genus. Kelimpahan zooplankton tertinggi ditemukan pada stasiun 1 rawa nebong kuning dan stasiun 3 rawa banan dengan nilai rata-rata 1,75ind/L dan 1,5 ind/L yang mengindikasikan tingkat kesuburan perairan rawa banjiran termasuk dalam kategori mesotrofik dan terendah pada stasiun 2 rawa poron dengan nilai rata-rata 0,92 ind/Lyang mengindikasikantingkat
\end{abstract}


kesuburan perairan rawa banjiran Desa Sedang Kecamatan Suak Tapeh Kabupaten Banyuasin termasuk dalam kategorioligotrofik.

Kata Kunci: kelimpahan, zooplankton, rawa banjiran, kesuburan perairan

\section{PENDAHULUAN}

Zooplankton merupakan konsumen pertama yang memanfaatkan produksi primer yang dihasilkan oleh fitoplankton. Peranan zooplankton sebagai konsumen pertama yang menghubungkan fitoplankton dengan karnivora kecil maupun besar, dapat mempengaruhi kompleks atau tidaknya rantai makanan di dalam ekosistem perairan. Pola penyebaran dan struktur komunitas zooplankton dalam suatu perairan dapat dipakai sebagai salah satu indikator biologi dalam menentukan perubahan kondisi suatu perairan (Suherman, 2005dalam Iswanto, 2015).

Salah satu jenis perairan yang ada yaitu kawasanRawa Banjiran. Menurut Kordi (2008) dalam Yusanti (2019), Rawa Banjiran merupakan kawasan lahan rendah yang senantiasa memiliki kepekaan tergenang air baik dalam kurun waktu tertentu maupun sepanjang tahun. Rawa Banjiran Nebong Kuning, Poron dan Banan merupakan kawasan rawa banjiran yang terletak di Desa Sedang Kecamatan Suak Tapeh Kabupaten Banyuasin. Keberadaan rawa banjiran tersebut, oleh masyarakat setempat dimanfaatkan sebagai tempat pemukiman, kegiatan perkebunan bahkan dijadikan tempat rekreasi. Akibat banyaknya aktifitas dikawasan rawa banjiran, dikhawatirkan akan berpengaruh terhadap kualitas kesuburan perairan tersebut, yang secara langsung maupun tidak langsung akan mempengaruhi kondisi rantai makanan dan ekosistem rawa banjiran.

Tujuan dilakukannya penelitian ini adalah untuk mengetahui kelimpahan zooplankton sebagai indikator kesuburan perairan rawa banjiran di Desa Sedang Kecamatan Suak Tapeh Kabupaten Banyuasin.

\section{BAHAN DAN METODE}

\section{A. Lokasi dan Waktu}

Penelitian dilaksanakan pada bulan Juli 2017 di Rawa Banjiran Desa Sedang Kecamatan Suak Tapeh Kabupaten Banyuasin.

\section{B. Alat dan Bahan}

Alat yang digunakan dalam penelitian ini antara lain : mikroskop, plankton net no 25, ember plastik, secchi disk, thermometer, DO meter, $\mathrm{pH}$ meter, kamera, botol film, kertas label, pipet tetes, alat tulis, gelas ukur, Sedgwick rafter/cover glass. Sedangkan bahan yang digunakan adalah air sampel yang diambil dari rawa banjiran dan formalin $4 \%$.

\section{Metode Penelitian}

Metode penelitian menggunakan metode deskriptif yang memberikan deskripsi atau gambaran mengenai keanekaragaman zooplankton di Rawa Banjiran Desa Sedang Kecamatan Suak Tapeh Kabupaten Banyuasin. Pengambilan sampel menggunakan metode purposive random sampling.

\section{Prosedur Penelitian Zooplakton \\ Lokasi Pengambilan Sampel}

Pengambilan sampel zooplankton dilakukan pada 3 (tiga) titik stasiun pengambilan sampel di Rawa Banjiran Desa Sedang Kecamatan Suak Tapeh Kabupaten Banyuasinyaitu : 
a. Stasiun 1 Rawa Nebong Kuning, memiliki luas $84.000 \mathrm{~m}^{2}$ dengan kedalaman rawa berkisar $2,5 \mathrm{~m}$ hingga $4 \mathrm{~m}$. Titik sampling stasiun 1 Rawa Nebong Kuning ini memiliki jarak terdekat dengan rumah penduduk adalah $350 \mathrm{~m}$

b. Stasiun 2 Rawa Poron, memiliki luas wilayah $41.800 \mathrm{~m}^{2}$ dengan kedalaman rawa berkisar antara 2,3 $\mathrm{m}$ hingga 3 m. Stasiun 2 Rawa Poronterletak 750 $\mathrm{m}$ dari rumah penduduk dan berjarak sekitar $850 \mathrm{~m}$ dari stasiun 1. Pada stasiun ini tidak terdapat banyak aktivitas penduduk.

c. Stasiun 3 Rawa Banan, memiliki luas wilayah $31.200 \mathrm{~m}^{2}$. Stasiun 3 Rawa Banan dengan kedalaman rawa berkisar antara 2,3 m- 3,8 m terletak $200 \mathrm{~m}$ dari rumah penduduk, sedangkan jarak antara stasiun 3 rawa banan ke stasiun 2 Rawa Poron adalah $1.050 \mathrm{~m}$. Sementara itu, jarak stasiun 3 rawa banan ke stasiun 1 Rawa Nebong Kuning berkisar 1.900 m. Pada stasiun ini tidak terdapat banyak aktivitas penduduk.

\section{Pengambilan SampelZooplankton}

Sampel air diambil menggunakan ember berukuran 5L sebanyak 20 kali. Kemudian sampel air di saring menggunakan plankton-net berukuran no 25 mesh yang ujungnya di pasang botol pengumpul. Kemudian botol pengumpul dilepas dan air dipindahkan ke dalam botol sampel volume $25 \mathrm{ml}$. Air dalam botol sampel diawetkan menggunakan formalin $4 \%$ sebanyak 5 tetes, kemudian ditutup dan diberi label (Yusanti, 2018)

\section{Identifikasi Zooplakton}

Identifikasi zooplankton dilakukan di Balai Riset Perikanan Perairan Umum Palembang dengan menggunakan mikroskop dan Sedgwick rafter. Pengamatan jenis zooplankton mengacu pada buku panduan identifikasi Mizuno (1979).

\section{E. Analisa Data \\ Kelimpahan Plankton}

Kelimpahan

zooplankton

diperoleh dengan melakukan perhitungan jumlah individu tiap liter sampel air mengacu padaAPHA (2005)dalam Indrayani (2014).

$$
\square N=\frac{\mathrm{vs} \mathrm{xvc}}{\mathrm{ns} \mathrm{xva}}
$$

Keterangan :

$\mathrm{N}=$ jumlah plankton per liter air contoh $\mathrm{ns}=$ jumlah plankton pada sedgewickrafter counting cell

$\mathrm{va}=$ volume air terkonsentrasi dalam botol contoh (cc) (25ml)

vs $=$ volume air dalam preparat sedgewick-rafter counting cell $(1 \mathrm{ml})$

$\mathrm{vc}=$ volume air contoh yang disaring (100L)

\section{F. Pendugaan Status Trofik}

Pendugaanstatus tropik berdasarkan kelimpahan zooplankton mengacu pada Goldman dan Horne (1994) dalam Suryanto (2009).

- Oligotrofik yaitu perairan tersebut mempunyai tingkat kesuburan rendah dengan kelimpahan zooplankton kurang dari 1 ind/lt,

- Mesotrofik yaitu perairan yang mempunyai tingkat kesuburan sedang dengan kelimpahan zooplankton antara 1-500 ind/lt,

- Eutrofik yaitu perairan yang mempunyai tingkat kesuburan tinggi dengan kelimpahan zooplankton lebih dari 500 ind/lt.

\section{HASIL DAN PEMBAHASAN}

Berdasarkan hasil identifikasi komposisi zooplankton di Rawa Banjiran Desa Sedang Kecamatan Suak Tapeh Kabupaten Banyuasin diperoleh 3 (tiga) kelas, yaitu Monogononta, Mastigophora dan Ciliata.Selengkapnya disajikan pada Tabel 1 berikut ini. 
Tabel 1. Komposisi zooplankton berdasarkan kelas di Rawa Banjiran DesaSedang Kecamatan Suak Tapeh Kabupaten Banyuasin.

\begin{tabular}{|c|c|c|c|c|c|c|}
\hline \multirow[b]{2}{*}{ No } & \multirow[b]{2}{*}{ Kelas } & \multirow[b]{2}{*}{ Genus } & \multicolumn{3}{|c|}{ Stasiun } & \multirow[b]{2}{*}{ Total } \\
\hline & & & $\begin{array}{c}\text { Rawa } \\
\text { Nebong } \\
\text { Kuning }\end{array}$ & $\begin{array}{l}\text { Rawa } \\
\text { Poron }\end{array}$ & $\begin{array}{l}\text { Rawa } \\
\text { Banan }\end{array}$ & \\
\hline 1 & Monogonota & & & & & \\
\hline \multirow{6}{*}{2} & & Trichocerca & 2 & - & 1 & 3 \\
\hline & & Difflugia & 4 & 5 & 7 & 16 \\
\hline & & Euglena & 1 & 2 & 8 & 11 \\
\hline & & Peridinium & 1 & - & - & 1 \\
\hline & & Phacus & 5 & 2 & - & 7 \\
\hline & & Trachelomonas & 3 & 2 & - & 5 \\
\hline \multirow[t]{4}{*}{3} & Ciliata & & & & & \\
\hline & & Actinophyrius & 4 & - & - & 4 \\
\hline & & Coleps & 1 & - & 2 & 3 \\
\hline & & Jumlah & 21 & 11 & 18 & 50 \\
\hline
\end{tabular}

Dari Tabel 1 dapat dilihat bahwa komposisi zooplankton di Rawa Banjiran Desa Sedang Kecamatan Suak Tapeh Kabupaten Banyuasin pada stasiun 1 rawa nebong kuning diperoleh 3 kelas yaitu Monogonota (Trichocerca), Mastigophora (Difflugia, Euglena, Peridinium, Phacus, Trachelomonas) dan Ciliata (Coleps). Pada stasiun 2 rawa poron diperoleh 1 kelas yaitu Mastigophora (Difflugia, Euglena, Phacus, Trachelomonas), sedangkan stasiun 3 rawa banan diperoleh 3 kelas yaitu Monogonota (Trichocerca), Mastigophora (Difflugia, Euglena) dan Ciliata (Coleps).

Difflugia dan Euglena merupakan genus yang ditemukan disetiap stasiun pengambilan sampling, serta memiliki total kelimpahan tertinggi dibandingkan genus lainnya. Hal ini diduga karena kelas Mastigophorabanyak ditemukan dan mampu beradaptasi dengan lingkungan perairan. Dugaan ini selaras dengan pendapat Yusanti (2018) yang menyatakan bahwa kelas mastigophoramerupakan bagian dari filum protozoa yang mudah beradaptasi dengan kondisi lingkungan. Selain itu, Suryanto (2009) dalam Prima (2015) menambahkan bahwa filum protozoa adalah kelompok hewan yang melayang atau mengapung dalam air, umumnya berhabitat di air tawar, laut atau estuari bahkan sampai habitat teresterial.

Nilai indeks kelimpahan Zooplankton pada setiap stasiun pengambilan sampel di Rawa Banjiran Desa Sedang Kecamatan Suak Tapeh Kabupaten Banyuasin disajikan pada Tabel 2.

Pada Tabel 2 disajikan data indeks kelimpahan zooplankton di rawa banjiran Desa Sedang Kecamatan Suak Tapeh Kabupaten Banyuasin Provinsi Sumatera Selatan, dimana pada stasiun 1 rawa nebong kuning diperoleh nilai ratarata kelimpahan fitoplankton sebesar 1,75ind/l, stasiun 2 rawa poron sebesar 0,92 ind/ldan stasiun 3 rawa banan sebesar 1,5 ind/l. Nilai indeks kelimpahan zooplankton tertinggi di dapatkan pada stasiun 1 rawa nebong kuning, diikuti oleh stasiun 3 rawa banan dan terendah pada stasiun 2 rawa poron. 
Tabel 2. Kelimpahan Zooplankton (N) di Rawa Banjiran Desa Sedang Kecamatan Suak Tapeh Kabupaten Banyuasin.

\begin{tabular}{|c|c|c|c|c|c|c|c|c|c|c|c|}
\hline \multirow{3}{*}{ No } & \multirow{3}{*}{ Genus } & \multicolumn{9}{|c|}{ Kelimpahan (ind/L) } & \multirow{3}{*}{$\begin{array}{c}\text { Total } \\
\text { Kelimpahan } \\
\text { (ind/L) }\end{array}$} \\
\hline & & \multicolumn{3}{|c|}{$\begin{array}{l}\text { Rawa Nebong } \\
\text { Kuning }\end{array}$} & \multicolumn{3}{|c|}{ Rawa Poron } & \multicolumn{3}{|c|}{ Rawa Banan } & \\
\hline & & 1 & 2 & 3 & 1 & 2 & 3 & 1 & 2 & 3 & \\
\hline \multirow[t]{2}{*}{1} & Monogononta & & & & & & & & & & \\
\hline & Trichocerca & 0,25 & - & 0,25 & - & - & - & - & - & 0,25 & 0,75 \\
\hline \multirow[t]{6}{*}{2} & Mastigophora & & & & & & & & & & \\
\hline & Difflugia & 0,75 & - & 0,25 & - & - & 1,25 & 0,75 & 0,25 & 0,75 & 4 \\
\hline & Euglena & 0,25 & - & - & - & - & 0,5 & 0,25 & - & 1,75 & 2,75 \\
\hline & Peridium & 0,25 & - & - & - & - & - & - & - & - & 0,25 \\
\hline & Phacus & 0,5 & 0,75 & - & 0,5 & - & - & - & - & - & 1,75 \\
\hline & Trachelomonas & 0,75 & - & - & - & - & 0,5 & - & - & - & 1,25 \\
\hline \multirow[t]{5}{*}{3} & Ciliata & & & & & & & & & & \\
\hline & Actinophyrius & - & 0,25 & 0,75 & - & - & - & - & - & - & 1 \\
\hline & Coleps & - & - & 0,25 & - & - & - & 0,5 & - & - & 0,75 \\
\hline & Total & 2,75 & 1 & 1,5 & 0,5 & - & 2,25 & 1,5 & 0,25 & 2,75 & 12,5 \\
\hline & Rata-rata & & 1,75 & & & 0,9 & & & 1,5 & & 4,17 \\
\hline
\end{tabular}

Tingginya

kelimpahan zooplankton di stasiun 1 rawa nebong kuning dan stasiun 2 rawa banan, diduga dipengaruhi oleh adanya ketersediaan sumber makanan bagi zooplankton. Makanan merupakan faktor utama yang sangat mempengaruhi pertumbuhan zooplankton. Menurut Muninggar et al (2015), zooplankton merupakan konsumen pertama yang memanfaatkan produksi primer yang dihasilkan fitoplankton. Peranan zooplankton sebagai mata rantai antara produsen primer dengan karnivora besar dan kecil dapat mempengaruhi kompleksitas rantai makanan dalam ekosistem perairan sehingga keberadaan zooplankton berbanding lurus dengan keberadaan fitoplankton.Fitoplankton merupakan makanan bagi zooplankton, berfungsi sebagai pakan alami di perairan. Yuliana (2012) dalam Yusanti (2017) menyatakan bahwa ketersediaan fitoplankton yang mengandung protein, karbohidrat, lemak, vitamin dan mineral akan memenuhi kebutuhan nutrisi dan mempengaruhi keberlangsungan hidup ikan dan organisme lainnya di perairan. Selain sebagai produsen makanan, fitoplankton juga berperan sebagai indikator tingkat kesuburan suatu perairan.

Dugaan tersebut di dukung oleh Yuliana (2017) yang menyatakan bahwa kehadiran dan kelimpahan zooplankton sangat erat kaitannya dengan perubahan lingkungan dan ketersediaan makanan. Zooplankton hanya dapat hidup dan berkembang dengan baik pada kondisi perairan yang sesuai seperti perairan laut, sungai, dan waduk. Selain itu, Hutabarat dan Evans (1985) dalam Prasetyaningtyas (2012), menambahkan bahwa zooplankton yang bersifat heterotrof akan memakan fitoplankton secara langsung, sedangkan secara tidak langsung zooplankton yang herbivora akan dimakan oleh zooplankton karnivora dan hewan lainnya yang berukuran lebih besar, termasuk ikan.

Rendahnya nilai kelimpahan zooplankton di stasiun 2 rawa poron diduga karena kondisi lingkungan perairan tersebut kurang stabil atau tidak sesuai dengan kebutuhan hidup zooplankton. Hal ini sesuai dengan pendapat Thoha (2004) dalam Yuliana (2017) yang menyatakan bahwa apabila kondisi lingkungan sesuai dengan 
kebutuhan zooplankton, maka zooplankton akan tumbuh dan berkembang dengan baik. Begitu pula sebaliknya, jika kondisi lingkungan dan ketersediaan fitoplankton tidak sesuai dengan kebutuhan zooplankton, maka zooplankton tidak dapat bertahan hidup dan akan mencari kondisi lingkungan yang sesuai. Pendapat tersebut sejalan dengan pernyataan yang dikemukakan oleh Indrayani (2014) dalam Yusanti (2019) yang menyatakan bahwa, kelimpahan plankton (fitoplankton dan zooplankton) pada suatu perairan erat kaitannya dengan kondisi lingkungan pada perairan tersebut.

Mengacu pada Goldman dan Horne (1994) dalam Suryanto (2009), maka stasiun 1 rawa nebong kuning dengan rata-rata kelimpahan zooplankton sebesar 1,75 ind/1 dan stasiun 3 rawa banan dengan rata-rata kelimpahan zooplankton sebesar 1,5 ind/l termasuk dalam kategori tingkat kesuburan sedang dan digolongkan perairan mesotrofik dengan nilai kelimpahan zooplankton berkisar antara 1,5 ind/1 dan 1,75 ind/l,sedangkan stasiun 2 rawa poron dengan rata-rata kelimpahan zooplankton sebesar 0,92 ind/l termasuk dalam kategori tingkat kesuburan rendah dan tergolong perairan oligotrofik.

\section{KESIMPULAN}

Indeks Kelimpahan rata-rata zooplankton pada stasiun 1 rawa nebong kuning sebesar1,75 ind/L, stasiun 2 rawa poron sebesar0,92 ind/L, stasiun 3 rawa banan sebesar1,5 ind/L. Nilai indeks kelimpahan fitoplankton tersebut berdasarkan pengindeksan Goldman dan Horne (1994) dalam Suryanto (2009), mengindikasikan bahwa perairan rawa banjiran di Desa Sedang Kecamatan Suak Tapeh Kabupaten Banyuasin Provinsi Sumatera Selatan,pada stasiun 1 rawa nebong kuning dan stasiun 3 rawa banan memiliki tingkat kesuburan yang sedang dan termasuk perairan mesotrofik, sedangkan stasiun 2 rawa poron memiliki tingkat kesuburan yang rendah dan termasuk perairan oligotrofik.

\section{DAFTAR PUSTAKA}

Indrayani, N. Anggoro, S., Suryanto, A. 2014. Indeks Tropik-Saprobik Sebagai Indikator Kualitas Air di Bendungan Kembang Kempis Wedung Kabupaten Demak. Diponegoro Journal of Maquares. Vol.3 No.4 : 161 - 168

Mizuno, T. (1979). Illustrations of The Freshwater Plankton of Japan. Hoikusha Publishing, Co., Ltd. p353.

Ningrum, AM., Wijiyono. 2015. Zooplankton Sebagai Indikator Biologi Pada Ekosistem Perairan Kolam Bioremediasi Psta- Batan.

Odum, E.P. (1993). Dasar-dasar Ekologi. Terjemahan: Tjahjono Samingan dan B. Srigando. Edisi Ketiga.Gadjahmada University Press. Yogyakarta. xv+613hlm

Prasetyaningtyas, T., Priyono, B., Pribadi, T.A. 2012. Keanekaragaman Plankton Di Perairan Tambak Ikan Bandeng Di Tapak Tugurejo Semarang. Unnes Journal of Life Science (1). p55-61

Prima, D. (2015). Keanekaragaman dan Kelimpahan Zooplankton di Sungai Ekang Anculai Kecamatan Teluk Sebong Kabupaten Bintan. Diakses dari website :jurnal.umrah.ac.id/wpcontent/uploa ds/gravity_forms/1.../09/Dodyjurnal.pdf).

Suryanto, A.M., Umi, H.S. 2009. Pendugaan Status Trofik Dengan Pendekatan Kelimpahan Fitoplanktondan Zooplankton DiWaduk Sengguruh, Karangkates, 
Lahor, Wlingi Raya dan Wonorejo Jawa Timur.Jurnal Ilmiah Perikanan dan Kelautan. Vol 1(1):7-13

Yuliana. Ahmad, F. 2017. Komposisi Jenis dan Kelimpahan Zooplankton di Perairan Teluk Buli, Halmahera Timur. Jurnal Ilmiah Agribisnis dan Perikanan. Vol.10 (2) : 44-50

Yusanti, IA. Widayatsih, T. 2017. Keanekaragaman Fitoplankton di Rawa Banjiran Kecamatan Suak Tapeh Kabupaten Banyuasin. Prosiding Lahan Suboptimal.

Yusanti, IA. Widayatsih, T. Ramadhan. 2018. Keanekaragaman Zooplankton di Rawa Banjiran Kecamatan Suak Tapeh Kabupaten Banyuasin. Jurnal Biota. Vol 1 (1) :7-11

Yusanti, IA. 2019. Pendugaan StatusTrofik Rawa Banjiran Desa Sedang Kecamatan Suak TapehKabupaten Banyuasin dengan Pendekatan Kelimpahan Fitoplankton. Jurnal Enggano. Vol.4 (1) 